\title{
The X-linked Retinitis Pigmentosa protein RP2 facilitates traffic of cilia target proteins
}

\author{
N Schwarz ${ }^{1,2^{*}}$, TV Novoselova ${ }^{1}$, R Wait ${ }^{3}$, AJ Hardcastle ${ }^{1}$, ME Cheetham ${ }^{1}$ \\ From First International Cilia in Development and Disease Scientific Conference (2012) \\ London, UK. 16-18 May 2012
}

Photoreceptors are specialized ciliated sensory neurons and aberrant traffic of proteins to the outer segment causes photoreceptor cell death. RP2 is a GTPase activating protein (GAP) for the small GTPase Arl3 and both proteins facilitate protein trafficking to primary cilia. We used GST-RP2 pull down from retinal lysates and identified the G $\beta$ subunit of transducin (Gß1) as a novel RP2 interacting protein. RP2 competes with G $\gamma 1$ for G $\beta 1$ binding and does not interact with the $G \beta: G \gamma$ heterodimer. In SK-N-SH cells, overexpression of G $\beta 1$ resulted in the cytoplasmic accumulation of the protein, whereas coexpression of G $\beta 1$ with either RP2 or G $\gamma 1$ restored membrane association of G $\beta 1$. Depletion of RP2 in ARPE19 cells by siRNA resulted in a shift of G $\beta 1$ from the membrane to the cytosol, confirming that RP2 facilitates the membrane association of G $\beta 1$. This shift in G $\beta 1$ localization was rescued by $\mathrm{G} \gamma 1$ overexpression. Membrane targeting of G $\beta 1$ required RP2 N-terminal myristoylation and occurs via the co-factor $\mathrm{C}$ (TBCC) homology domain. The interaction was disrupted by the pathogenic RP2 mutation R118H, which blocks Arl3 GAP activity. Arl3-Q71L competed with G $\beta 1$ for RP2 binding suggesting that RP2 GAP activity on Arl3 would release G $\beta 1$. RP2 stimulated the association of G $\beta 1$ with Rab11, an important GTPase for post-Golgi vesicle trafficking of photoreceptor proteins. Collectively our data support a role for RP2 in facilitating membrane association and traffic of G $\beta 1$. Combined with other recent evidence, this suggests that RP2 may co-operate with Arl3 and its effectors in cilia associated trafficking of $\mathrm{G}$ proteins.

\section{Author details \\ ${ }^{1} \mathrm{UCL}$, Institute of Ophthalmology, UK. ${ }^{2} \mathrm{ORBIT}$, UK. ${ }^{3}$ Kennedy Institute of Rheumatology Division, Imperial College London, UK.}

\footnotetext{
* Correspondence: n.schwarz@ucl.ac.uk

'UCL, Institute of Ophthalmology, UK

Full list of author information is available at the end of the article
}

Published: 16 November 2012

\section{doi:10.1186/2046-2530-1-S1-P45}

Cite this article as: Schwarz et al:: The X-linked Retinitis Pigmentosa protein RP2 facilitates traffic of cilia target proteins. Cilia 2012 1(Suppl 1): P45.
Submit your next manuscript to BioMed Central and take full advantage of:

- Convenient online submission

- Thorough peer review

- No space constraints or color figure charges

- Immediate publication on acceptance

- Inclusion in PubMed, CAS, Scopus and Google Scholar

- Research which is freely available for redistribution
C Biomed Central 